\title{
Research Paper Prognostic value of tumor mutations in radically treated locally advanced non-small cell lung cancer patients
}

\author{
Angela Boros ${ }^{1}$, Ludovic Lacroix ${ }^{2}$, Benjamin Lacas ${ }^{3,8,10}$, Julien Adam², Jean-Pierre \\ Pignon $^{3,8,10}$, Caroline Caramella ${ }^{4}$, David Planchard ${ }^{5}$, Vincent de Montpreville ${ }^{6}$, Eric \\ Deutsch $^{1,7,9}$, Antonin Levy ${ }^{1}$, Benjamin Besse ${ }^{5,7}$, Cécile Le Pechoux ${ }^{1}$ \\ ${ }^{1}$ Radiation Oncology Department, Gustave Roussy, Villejuif, France \\ ${ }^{2}$ Biopathology Department, Gustave Roussy, Villejuif, France \\ ${ }^{3}$ Biostatistics and Epidemiolgy Unit, Villejuif, France \\ ${ }^{4}$ Imaging Department, Gustave Roussy, Villejuif, France \\ ${ }^{5}$ Medical Oncology Department, Gustave Roussy, Villejuif, France \\ ${ }^{6}$ Pathology Department, Marie Lannelongue, Le Plessis Robinson, France \\ ${ }^{7}$ Paris-Sud University, DHU TORINO, Paris, France \\ ${ }^{8}$ Paris-Saclay University, Paris, France \\ ${ }^{9}$ INSERM U1030, Villejuif, France \\ ${ }^{10}$ INSERM U1018, Villejuif, France \\ Correspondence to: Benjamin Besse, email: Benjamin.BESSE@gustaveroussy.fr
}

Keywords: locally advanced, non-small cell lung cancer, mutation, prognostic, chemotherapy

Received: July 04, 2016

Accepted: February 15, 2017

Published: March 07, 2017

Copyright: Boros et al. This is an open-access article distributed under the terms of the Creative Commons Attribution License (CC-BY), which permits unrestricted use, distribution, and reproduction in any medium, provided the original author and source are credited.

\section{ABSTRACT}

Introduction: Chemo-radiation is standard treatment in locally advanced nonsmall cell lung cancers (NSCLC). The prognostic value of mutations has been poorly explored in this population.

Results: Clinical data were collected from 190 patients and mutational profiles were obtained in 78 of them; 58 (74\%) were males, $31(40 \%)$ current smokers, $47 / 31$ stage IIIA/IIIB and $40(51 \%)$ adenocarcinoma. The following mutations were identified: EGFR 12\% (9/78), KRAS 15\% (12/78), BRAF 5\% (3/65), PI3KCA 2\% (1/57), NRAS 3\% (1/32), and ALK+ (FISH) 4\% (2/51). HER2 was not detected. Median follow-up was 3.1 years. Overall survival was evaluated by group; no significant differences were identified in median overall survival $(p=0.21)$, with 29.4 months for the EGFR/ALK group $(n=11), 12.8$ months for other mutations $(n=17)$, and 23.4 months for wild-type $(n=50)$. The EGFR/ALK and other mutations groups had poorer median progression-free survival (9.6 and 6.0 months) compared to the wild-type group (12.0 months; multivariate hazard ratio 2.0 [95\% CI, $0.9-4.2$ ] and $2.8[95 \%$ CI, $1.5-5.2]$ respectively, $p=0.003$ ).

Materials and Methods: We retrospectively reviewed all patients receiving radical treatment for locally advanced NSCLC in a single institution between January 2002 and June 2013. Next generation sequencing was performed on DNA from paraffinembedded tissue. $A L K$ rearrangements were detected by immunohistochemistry and/or FISH. Mutational prognostic value for Kaplan-Meier survival parameters was determined by log-rank tests and Cox proportional hazards models.

Conclusions: Selected gene alterations may be associated with poorer progression-free survival in locally advanced radically treated NSCLC and their prognostic and/or predictive value merits further evaluation in a larger population. 


\section{INTRODUCTION}

Molecular profiling has become a standard procedure in advanced non-small cell lung cancer (NSCLC). Specific tyrosine kinase oncogenic activation, especially epidermal growth factor receptor $(E G F R)$ mutations or rearrangement of the anaplastic lymphoma kinase $(A L K)$ gene, led to the development of targeted molecular inhibitors and a specific therapeutic strategy in this patient subgroup $[1,2,3]$. Uncommon NSCLC mutations such as HER2, BRAF and PI3KCA might also be relevant targets $[4,5]$. In advanced NSCLC, the presence of an EGFR or the BRAF V600 mutation confers a more favorable prognosis while the $K R A S$ mutation is associated with worse outcomes $[6,7]$.

The standard of care in inoperable stage III NSCLC patients with good performance status is concomitant chemo-radiation, conferring an absolute benefit of $4.5 \%$ in terms of 5-year survival compared to sequential chemoradiation [8] for patients with no or limited comorbidities and adequate organ function $[9,10]$. There is no standard chemotherapy regimen, but platinum-based doublets are associated with better progression-free survival (PFS) [8]. While treatment choice guided by gene alterations is a widely-used strategy in stage IV NSCLC, molecular abnormalities rarely influence treatment choices in locally advanced NSCLC patients and furthermore, the outcome according to gene alterations is unknown. This study was designed to explore the prognostic value of specific gene alterations in locally advanced NSCLC patients, in light of moving towards personalized treatment strategies in this patient population.

\section{RESULTS}

\section{Patients and treatments}

Among the 190 eligible patients, 84 patients (44\%) had available data for at least one marker. Six were excluded because of missing data for $K R A S$ and/or $E G F R$ (Figure 1). The populations with and without available mutation data were well balanced, except for stage and diabetes (more patients with stage IIIA and diabetes in the population with data (Table 1).

Among the 78 patients with available mutation data, $58(74 \%)$ were male, 31 (40\%) were current smokers, 40 (51\%) had adenocarcinoma, 47 patients $(60 \%)$ had stage IIIA, and 31 patients (40\%) had IIIB. An initial positron emission tomography scan (PET-CT) was performed on 66 patients $(85 \%)$. Most patients $(62,79 \%)$ had conformal radiotherapy, with a median dose of $66 \mathrm{~Gy}$ in 33 fractions (f) and a median 48 days overall treatment time; three patients had moderate hypofractionated radiotherapy $(2.5 \mathrm{~Gy} / \mathrm{f})$ and one had split-course radiotherapy (55 Gy/20f). Eighteen patients (23\%) had a history of thoracic surgery, either with curative intent or at relapse. Twelve patients (15\%) had undergone curative surgery and received adjuvant radiotherapy. Five patients $(6 \%)$ had surgery without adjuvant treatment, undergoing radiotherapy for mediastinal relapse. One patient underwent surgery for local relapse. Platinumbased chemotherapy was concomitantly administered to 50 patients $(64 \%)$, as induction/consolidation treatment to 67 patients $(86 \%)$, and 7 patients did not receive chemotherapy, mainly because of poor performance status or age over 75 years. The most frequently administered chemotherapy regimen was cisplatin/vinorelbine (33 patients, 42\%). Median follow-up was 3.1 years.

\section{Mutation profiling}

Of the 78 patients analyzed, $28(36 \%)$ had a mutation. One had both an $A L K$ rearrangement and a $K R A S$ mutation, and was considered $A L K$ wild-type due to a higher prevalence of $K R A S$ mutation in reported NSCLC population. Another patient was KRAS mutant but was missing data for EGFR. Since KRAS and EGFR mutations were mostly mutually exclusive, this patient was considered $E G F R$ wild-type.

Mutations identified among the 78 patients (before considering missing data as wild-type) were EGFR $12 \%$ (9/78), KRAS 15\% (12/78), BRAF 5\% (3/65), PI3KCA $2 \%(1 / 57), N R A S 3 \%(1 / 32)$ and $A L K+$ (by FISH) in $4 \%(2 / 51)$. HER2 was not detected (Supplementary Table 1). Given the small patient numbers, the population was divided into three groups for prognostic analyses: 50 (64\%) in the wild-type group, $11(14 \%)$ in the $E G F R / A L K$ group, and $17(22 \%)$ in the other mutation group.

\section{Survival and prognostic factors}

Median survival was 23.4 months [ $95 \%$ confidence interval (CI) 18.2-29.1]. OS was not significantly different ( $p=0.21)$ between the three groups: 29.4 months [95\% CI 15.5 - not reached] for $E G F R / A L K, 12.8$ months [95\% CI 7.6-29.7] for other mutations and 23.4 months [95\% CI 17.8-29.9] for wild-type (Figure 2A). Of the 11 patients in the EGFR/ALK group, 7 had received targeted agents at recurrence. In the multivariate analysis, OS was not significantly different $(p=0.26)$ between the three groups, with a hazard ratio (HR) of $0.8[95 \%$ CI 0.3-2.0] and 1.6 [95\% CI 0.8-3.2] in the EGFR/ALK and other mutation groups, compared to the wild-type group, respectively (Table 2). Having a PET-scan was the only factor significantly associated with OS ( $\mathrm{HR}=0.3$ [95\% CI 0.1-0.6], $p=0.002$ ). A non-significant trend for better survival was associated with performance status 0 vs. $\geq 1$ (HR $=1.7$ [95\% CI 0.9-2.9]; $p=0.08)$.

The EGFR/ALK and other mutation groups had significantly poorer PFS (median: 9.6 months 
Table 1: Patient and treatment characteristics in patients with and without mutation profiling data

\begin{tabular}{|c|c|c|c|c|c|}
\hline & \multicolumn{2}{|c|}{$\begin{array}{c}\text { Mutation data } \\
\quad(N=78)\end{array}$} & \multicolumn{2}{|c|}{$\begin{array}{l}\text { No mutation data } \\
\quad(N=112)\end{array}$} & \multirow[t]{2}{*}{$\begin{array}{c}p \text {-value } \\
\left(\chi^{2}\right)\end{array}$} \\
\hline & $N$ & $\%$ & $N$ & $\%$ & \\
\hline Sex & & & & & 0.40 \\
\hline Female & 20 & 26 & 35 & 31 & \\
\hline Male & 58 & 74 & 77 & 69 & \\
\hline Age (years) & & & & & 0.27 \\
\hline$<60$ & 44 & 56 & 54 & 48 & \\
\hline$\geq 60$ & 34 & 44 & 58 & 52 & \\
\hline Median[range] & \multicolumn{2}{|c|}{$57.9[30.7 ; 88.9]$} & \multicolumn{2}{|c|}{$60.6[34.4 ; 85.0]$} & \\
\hline Performance status & & & & & 0.08 \\
\hline 0 & 38 & 49 & 69 & 62 & \\
\hline$\geq 1$ & 40 & 51 & 43 & 38 & \\
\hline Histology & & & & & 0.10 \\
\hline Adenocarcinoma & 40 & 51 & 44 & 39 & \\
\hline Other* & 38 & 49 & 68 & 61 & \\
\hline T-stage & & & & & 0.60 \\
\hline T0-T2 & 35 & 45 & 46 & 41 & \\
\hline T3-T4 & 43 & 55 & 66 & 59 & \\
\hline N-stage & & & & & 0.53 \\
\hline N0-N1 & 13 & 17 & 15 & 13 & \\
\hline $\mathrm{N} 2-\mathrm{N} 3$ & 65 & 83 & 97 & 87 & \\
\hline Stage & & & & & 0.001 \\
\hline IIIA & 47 & 60 & 41 & 37 & \\
\hline IIIB & 31 & 40 & 71 & 63 & \\
\hline Smoking status & & & & & 0.16 \\
\hline Current smoker & 31 & 40 & 56 & 50 & \\
\hline Never or former smoker & 47 & 60 & 56 & 50 & \\
\hline Diabetes & & & & & 0.04 \\
\hline No & 68 & 87 & 107 & 96 & \\
\hline Yes & 10 & 13 & 5 & 4 & \\
\hline Radiotherapy dose & & & & & 0.78 \\
\hline$<66$ Gy & 27 & 35 & 41 & 37 & \\
\hline$\geq 66$ Gy & 51 & 65 & 71 & 63 & \\
\hline Thoracic surgery & & & & & 0.06 \\
\hline No & 60 & 77 & 98 & 87 & \\
\hline Yes & 18 & 23 & 14 & 13 & \\
\hline
\end{tabular}

*Includes large cell carcinoma, mixed cell carcinoma, neuroendocrine markers, squamous cell carcinoma, undifferentiated tumor.

[95\% CI 7.2-10.8] and 6.0 months [95\% CI 4.8-9.6], respectively) than the wild-type group (median: 12.0 months [95\% CI 10.8-15.6]; $p=0.005$ ) (Figure 2B). In the multivariate analysis, HRs were 2.0 [95\% CI 0.9-4.2] for $E G F R / A L K$ and 2.8 [1.5; 5.2] for other mutation group; $p=0.003$ ) compared to wild-type (Table 3 ).
Taking into consideration the small number of patients in each mutational group, no difference was observed between the three groups regarding the pattern of failure of locoregional, metastatic, or locoregional and metastatic (Supplementary Table 2). Brain metastases were observed in 16 patients (21\%), 10 in the wild-type 
group, three in the $E G F R / A L K$ group and three in the other mutation group (Fisher test, $p=0.84$ ).

\section{DISCUSSION}

In recent years, mutation profiling has become increasingly important for defining the treatment strategy in stage IV NSCLC. As a result, improved OS has been observed in the subgroup of metastatic patients with targetable driver mutations such as EGFR mutations or $A L K$ rearrangements. The goal of this retrospective study was to evaluate whether molecular profiling has any role in the outcome for locally advanced NSCLC patients. We found that the presence of specific gene alterations was associated with poorer PFS; a significant HR superior or equal to 2 in multivariate analysis was observed between the $E G F R / A L K$ and wild-type groups, and other mutation and wild type groups. The corresponding median PFS were 9.6 months in the EGFR/ALK group, 6.0 months in the other mutation group and 12.0 months in the wildtype group. However when considering OS, there was no significant difference between the three groups, although there was a trend for improved OS in the EGFR/ALK group as many of these patients with actionable mutations received TKIs upon failure. While OS has historically been considered the most relevant and robust clinical endpoint, a recent large study supports PFS as a valid surrogate for OS in trials evaluating chemo-radiation in locally advanced lung cancer [11]. However, the efficacy observed with TKIs administered at relapse to patients with actionable driver mutations versus those without, supports the validity of PFS as an OS surrogate.

The prognostic value of mutations in NSCLC has been little studied in stage III patients, but has been the object of studies both in earlier and more advanced NSCLC. In a meta-analysis of surgically resected TKInaïve NSCLC patients, including stage I to IIIA, the presence of EGFR mutation was not prognostic [12]. This should be interpreted with caution considering the heterogeneity in patient selection, the adjustment or not for other prognostic factors, the follow-up and techniques used to detect EGFR mutations. Furthermore the presence of mutations is frequently observed in patients with better clinico-pathologic features such as never smokers or female gender [13]. A pooled analysis from three adjuvant chemotherapy trials of 295 patients with lung adenocarcinoma harboring KRAS wild-type and known $E G F R$ status did not find a correlation between $E G F R$ mutational status and prognosis or predictive value for OS and PFS [14].

Among patients with more advanced disease, EGFR mutations are an important predictive biomarker of TKI benefit in terms of PFS for all settings, front-line, maintenance, and second-line or subsequent therapy.

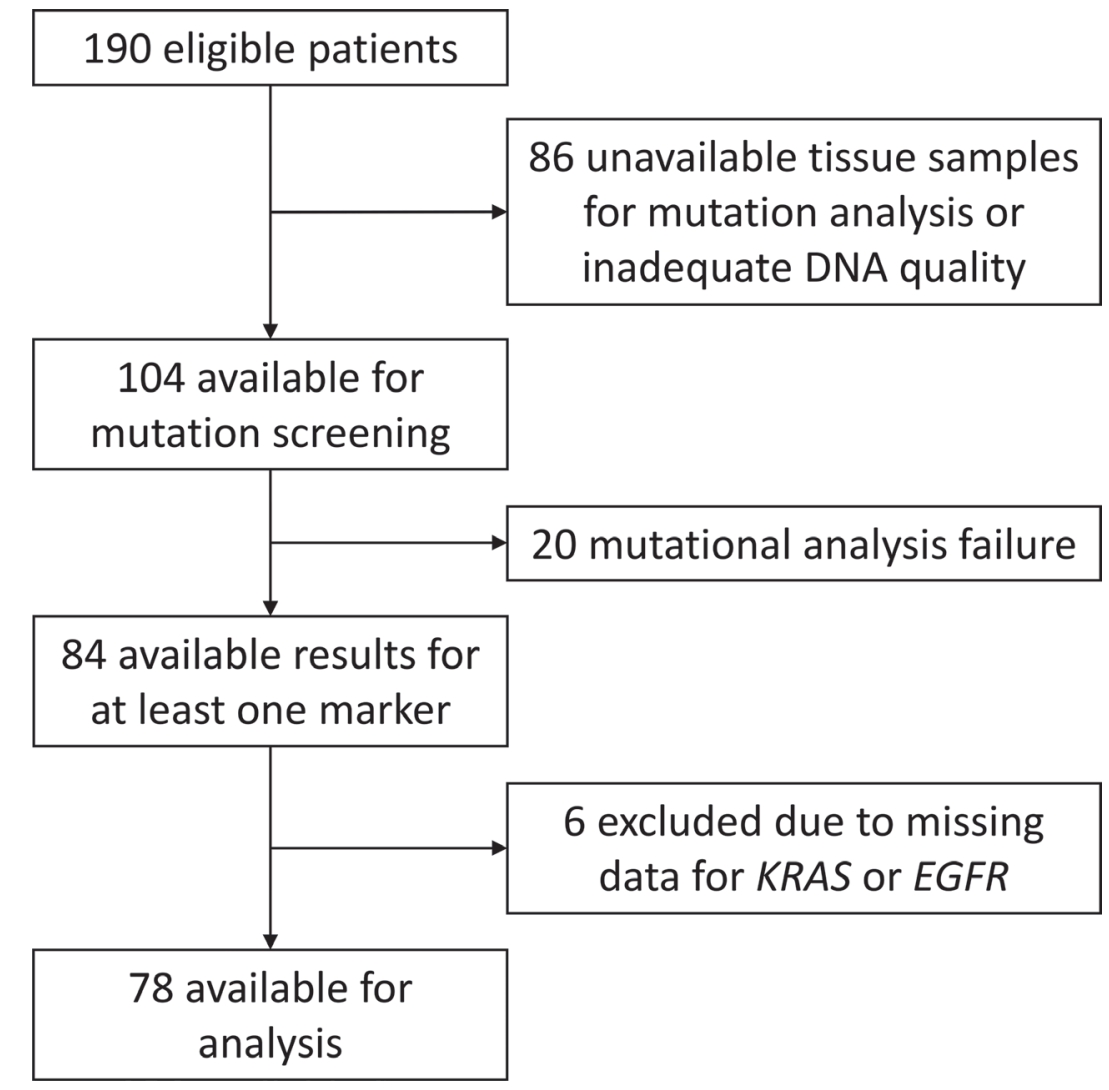

Figure 1: Patient flow chart. 
Table 2: Univariable and multivariable (Cox) analyses of prognostic factors for overall survival in the mutation analysis group

\begin{tabular}{|c|c|c|c|c|}
\hline & \multirow{2}{*}{$\begin{array}{l}\text { No. deaths / } \\
\text { No. patients }\end{array}$} & \multirow{2}{*}{$\frac{\text { Univariable }}{p \text {-value }}$} & \multicolumn{2}{|c|}{ Multivariable } \\
\hline & & & HR $[95 \% \mathrm{CI}]$ & $p$-value \\
\hline Mutation group & & 0.22 & & 0.26 \\
\hline All wildtype & $34 / 50$ & & Ref & \\
\hline$E G F R / A L K+$ & $6 / 11$ & & $0.8[0.3 ; 2.0]$ & \\
\hline Other mutation & $13 / 17$ & & $1.6[0.8 ; 3.2]$ & \\
\hline Performance status & & 0.08 & & 0.08 \\
\hline 0 & $23 / 38$ & & Ref & \\
\hline$\geq 1$ & $30 / 40$ & & $1.7[0.9 ; 2.9]$ & \\
\hline Stage & & 0.17 & & 0.10 \\
\hline IIIA & $29 / 47$ & & Ref & \\
\hline IIIB & $24 / 31$ & & $1.7[0.9 ; 3.0]$ & \\
\hline Radiotherapy dose & & 0.55 & & \\
\hline$<66$ Gy & $20 / 27$ & & & \\
\hline$\geq 66 \mathrm{~Gy}$ & $33 / 51$ & & & \\
\hline Thoracic surgery & & 0.16 & & 0.20 \\
\hline No & $42 / 60$ & & Ref & \\
\hline Yes & $11 / 18$ & & $0.6[0.3 ; 1.3]$ & \\
\hline PET scan & & 0.05 & & 0.002 \\
\hline No & $11 / 12$ & & Ref & \\
\hline Yes & $42 / 66$ & & $0.3[0.1 ; 0.6]$ & \\
\hline
\end{tabular}

$\mathrm{HR}=$ Hazard ratio $; \mathrm{CI}=$ Confidence interval Ref $=$ reference group .

Variables are included in the multivariable Cox model only if univariable $p$-value $<0.20$, except for mutation group since it is the studied variable.

Some published data suggest that EGFR mutations may be a positive prognostic factor irrespective of treatment for patients with advanced disease [15]. However, data on the prognostic value of EGFR mutations are scarce, lack data for untreated controls and generally have small sample sizes, meaning robust conclusions cannot be drawn $[16,17]$. Similarly, the prognostic value of $A L K$ rearrangement is not clearly established as contradictory results have been published $[18,19,20]$. To our knowledge, the current study is among the first evaluating the prognostic value of these mutations in patients with stage III treated by definitive radiotherapy treatment.

The other mutation group of our study, which was mainly $K R A S$, had a worse PFS than wild-type, with a significant HR of 2.8 in multivariate analysis. The negative prognostic impact of KRAS mutations in NSCLC suggested by two systematic reviews [21,22] was not confirmed in randomized trials evaluating adjuvant strategies in resected patients [23]. The pooled analysis of four large trials comparing adjuvant chemotherapy to observation did not find a significant prognostic value of KRAS mutation status among the 763 patients in the observation arm. Even if the type of mutation (codon 12 or 13) is not prognostic, further studies are needed to evaluate its predictive role [24]. More recently, studies have suggested that the prognostic impact of $K R A S$ mutation could be related to the presence of concurrent mutations such as STK11 that could define an aggressive subtype of lung cancer [25]. The prognostic value of other mutations as PI3KCA, BRAF, NRAS, or HER2 in NSCLC is poorly described, mostly because of their low incidence.

Another interesting observation, for which data in stage III patients are rare, is that patient characteristics and the distribution of mutations were similar to those observed in Caucasian populations with more advanced disease. The French National Cancer Institute established a national network in 2006, providing a routine panel of biomarkers, including EGFR, KRAS, BRAF, PI3KCA and $H E R 2$ mutations and $A L K$ rearrangements in patients with advanced NSCLC. Clinical characteristics and outcome for almost 18,000 patients was studied, [26] giving a distribution of EGFR mutations (11\%), $A L K$ rearrangements $(5 \%)$, PI3KCA (2\%), BRAF (2\%) and HER 2 mutations (1\%). The distribution in our study was similar, except for KRAS mutations which seemed to be 
more frequent in advanced disease (29\%), probably due to the higher incidence of adenocarcinoma [27].

The presence of specific gene alterations seems prognostic here, but no firm conclusions can be drawn from this small retrospective study. It nonetheless raises the question of the underlying mechanism explaining these findings. Could certain gene alterations be predictive of radio-sensitivity or radio-resistance? In this case, a different pattern of failure could be identified for each gene alteration, however no significant differences in terms of patterns of failure were observed across the three groups. OS was not significantly different between the three groups, with possibly better OS in the $E G F R / A L K$ group, the latter likely driven by subsequent TKIs at relapse. A meta-analysis showed improvement in PFS and overall response rate in advanced NSCLC receiving EGFR TKIs compared to chemotherapy, with no benefit in OS, probably because of the crossover between the two arms [28]. Knowledge of $E G F R$ status is therefore recommended for patient selection before EGFR-TKI therapy [29, 30].

A

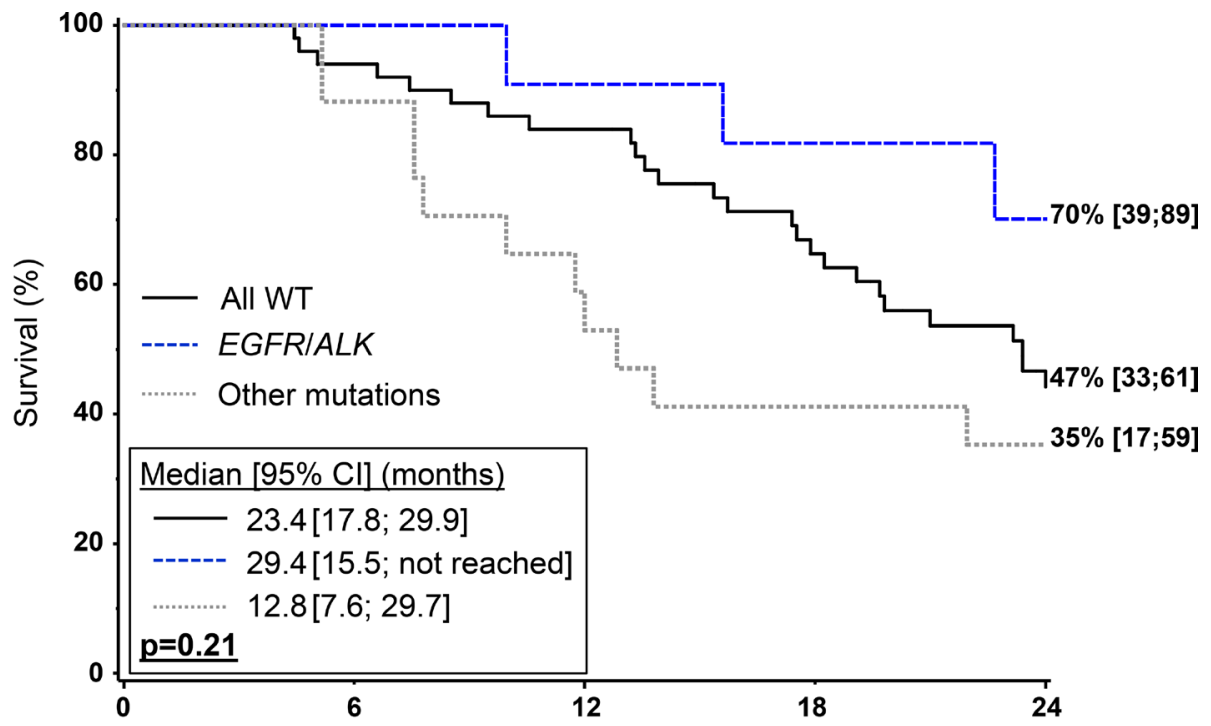

Patients at risk:

Time from inclusion (months)

$\begin{array}{rrrccr}- & 50 & 47 & 41 & 30 & 19 \\ ---- & 11 & 11 & 10 & 9 & 6 \\ \ldots \ldots . . & 17 & 15 & 9 & 7 & 6\end{array}$

B

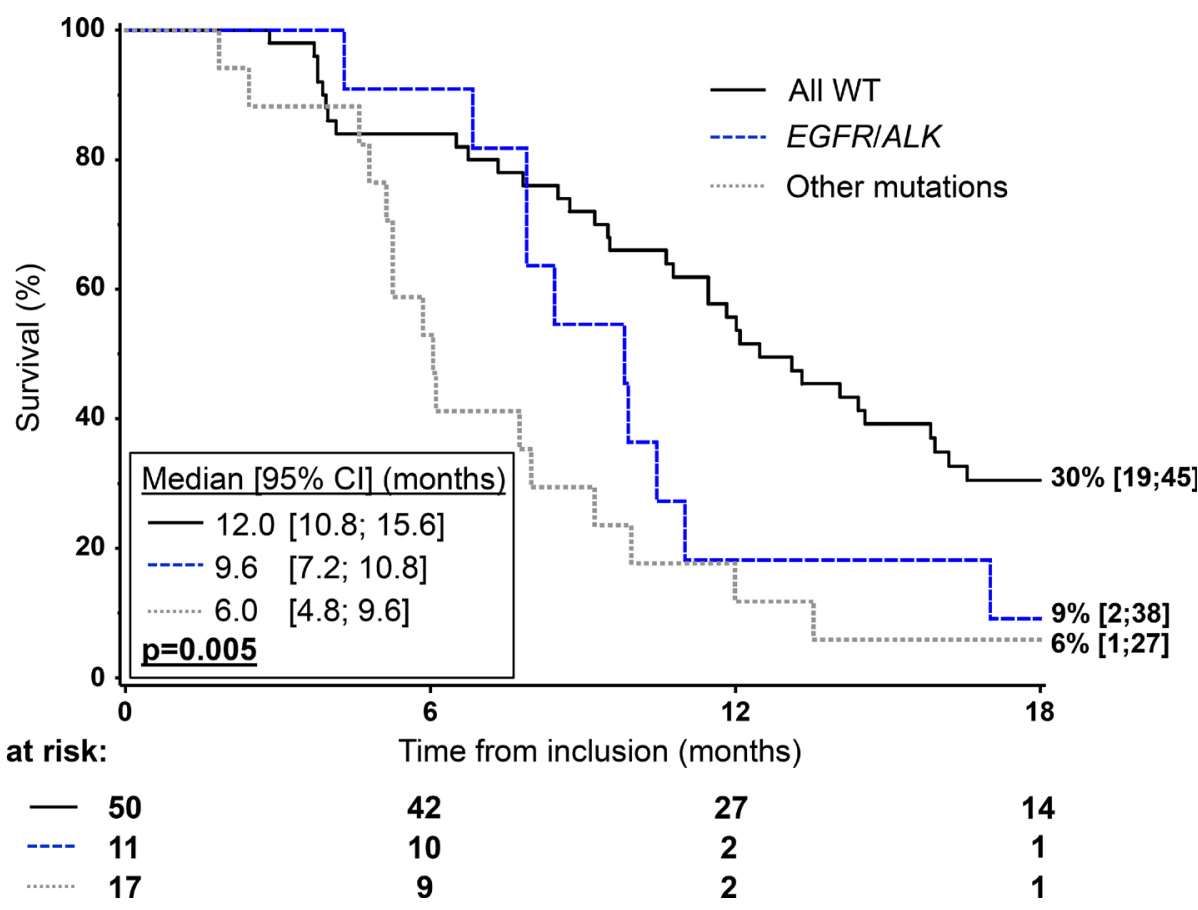

Figure 2: Kaplan-Meier analysis of overall survival (A) and progression-free survival (B) according to mutation status in the 78 patients with mutation profiling. 
Table 3: Multivariable Cox analysis of prognostic factors for progression-free survival in the mutation analysis group

\begin{tabular}{|c|c|c|c|}
\hline & No. events/No. patients & HR $[95 \% \mathrm{CI}]$ & $p$-value \\
\hline Mutation groups & & & 0.003 \\
\hline All wild-type & $41 / 50$ & Ref & \\
\hline$E G F R / A L K+$ & $10 / 11$ & $2.0[0.9 ; 4.2]$ & \\
\hline Other mutation & $16 / 17$ & $2.8[1.5 ; 5.2]$ & \\
\hline Performance status & & & 0.12 \\
\hline 0 & $32 / 38$ & Ref & \\
\hline$\geq 1$ & $35 / 40$ & $1.5[0.9 ; 2.5]$ & \\
\hline Stage & & & 0.21 \\
\hline IIIA & $39 / 47$ & Ref & \\
\hline IIIB & $28 / 31$ & $1.4[0.8 ; 2.4]$ & \\
\hline Thoracic surgery & & & 0.82 \\
\hline No & $52 / 60$ & Ref & \\
\hline Yes & $15 / 18$ & $0.9[0.5 ; 1.8]$ & \\
\hline PET scan & & & 0.14 \\
\hline No & $11 / 12$ & Ref & \\
\hline Yes & $56 / 66$ & $0.6[0.3 ; 1.2]$ & \\
\hline
\end{tabular}

$\mathrm{HR}=$ Hazard ratio $\mathrm{CI}=$ Confidence interval; $\mathrm{Ref}=$ reference group.

A difference in terms of local relapse suggestive of a direct relationship with an underlying mechanism of radio-resistance was not observed in our series, or for distance relapse, although results should be interpreted with caution due to the small sample size. The radio-resistance hypothesis was highlighted in a few studies suggesting the role of EGFR or KRAS mutation as radio-resistance markers and the use of therapeutics targeting the EGFR to overcome this resistance [31, 32]. Nevertheless, EGFR mutations as well as $A L K$ rearranged NSCLC were described as possible markers of radiosensitivity $[33,34]$. Promising results have been observed in patients with radiosensitive oncogene driver mutations, particularly with oligoprogressive disease, eligible for local treatment of selected metastases [35]. A similar study evaluating crizotinib in patients with stage IV $A L K+$ NSCLC and oligoprogressive extracranial disease who received local therapy, showed a PFS benefit [36]. The question of whether certain gene alterations could be predictive of radio-sensitivity or radio-resistance needs to be further explored for advanced stage and particularly for stage III NSCLC.

Progress in treatment of stage III disease is challenging, requiring both local and systemic optimal therapy. Recent phase III trials have shown better results with 2 -year survival rates surpassing $50 \%$, and median survival around 24 months [37, 38, 39]. Improved survival compared to historical series may be due to better selection and better treatment. In our study, as in most recently published phase III studies with stage III
NSCLC, most patients underwent PET-CT. Treatment modalities explored in phase III trials concern different chemoradiation schedules, radiotherapy dose escalation, implementation of TKIs such as cetuximab, as well as surgery or no surgery $[37,38,39]$. Several treatment options are thus available for stage III patients, combining chemotherapy, radiotherapy and/or surgery, as well as other promising strategies that need to be further explored $[40,41,42]$.

So what then is the best treatment option for an individual patient with stage III heterogeneous disease? Selected gene alterations may be associated with poorer PFS in locally advanced NSCLC patients, notably with respect to EGFR. Further studies in large populations are warranted to define the role of molecular determinants in these patients, their prognostic and/or predictive value, not only in terms of systemic treatment but also local treatment. If these results are confirmed, the strategy for locoregional management of stage III NSCLC could also be personalized based on the patients' molecular profile, a therapeutic management strategy which is already routine practice in stage IV NSCLC patients.

\section{MATERIALS AND METHODS}

\section{Eligibility}

Clinical data were reviewed from all consecutive patients in our institution who received chemo-radiation, 
exclusive radiotherapy or tri-modality treatment with a curative intent for primary or locally recurrent stage III NSCLC between January 2002 and June 2013. An electronic search was performed using a clinical data management system, a radiotherapy data management system and the MSN database (Identification of Marker of Primary or Acquired Resistance to Anti Tumorous Treatment; NCT02105168). Of the 356 patients screened, 190 were eligible. Reasons for exclusion were palliative radiotherapy, other histology, metastatic disease at diagnosis, or death before radiotherapy. Stage III disease was defined retrospectively according to IASLC/UICC7 [43] and histologic subtype was classified according to the WHO version for lung cancer [44]. Progression was defined as the first documented radiologic evidence according to RECIST v1.1.

\section{Mutational analysis}

Formalin-fixed, paraffin-embedded tissue blocks were collected and the presence of adequate tumor tissue was verified by the study pathologist. Analyses were performed for all samples and were considered as contributive only if more than $15 \%$ tumor cells were present. Mutational status was determined using next generation sequencing based on Ion Torrent with AmpliSeq Cancer Hotspot panel v2 (CHP2) panel as previously described [45]. In our hands, this approach offers a detection limit of 5\% with a high specificity and sensitivity as previously reported with equivalent approaches [46]. ALK rearrangements were screened with immunohistochemistry and confirmed by fluorescence in situ hybridization (FISH).

\section{Statistical analyses}

Seven markers were studied; if the mutation rate was less than $5 \%$ in the dataset, missing values were considered wild-type. Analyses were performed in three groups: wild-type (no mutations in any of the seven markers), EGFR/ALK, and "other mutation" (KRAS/NRAS/ $B R A F / P I K 3 C A / H E R 2)$. A mutant was defined as at least one mutated marker.

Patient characteristics were compared with a $\mathrm{Chi}^{2}$ test. Survival parameters were analyzed with the KaplanMeier method and mutational prognostic value was determined using the log-rank test and Cox proportional hazards models for which relevant variables were tested in a univariate analysis on overall survival (OS). If $p \leq 0.20$, variables were added to the multivariate Cox model. The model was adjusted on ECOG performance status $(0, \geq 1)$, stage (IIIA, IIIB), thoracic surgery (yes, no) and initial PETscan (yes, no). The same model was used for progressionfree survival (PFS). Median follow-up was estimated by the Schemper method [47]. Analyses were performed with SAS (version 9.3). All $p$-values were two-sided.

\section{ACKNOWLEDGMENTS}

We thank Melanie Laporte for technical assistance and Dr Sarah MacKenzie PhD for English editing.

\section{CONFLICTS OF INTEREST}

None.

\section{FUNDING}

Angela Boros was a recipient for the DUERTECC/ EURONCO grant (Diplôme Universitaire Européen de Recherche Translationnelle et Clinique en Cancérologie).

\section{REFERENCES}

1. Rosell R, Carcereny E, Gervais R, Vergnenegre A, Massuti B, Felip E, Palmero R, Garcia-Gomez R, Pallares C, Sanchez JM, Porta R, Cobo M, Garrido P, et al. Erlotinib versus standard chemotherapy as first-line treatment for European patients with advanced EGFR mutation-positive non-small-cell lung cancer (EURTAC): a multicentre, open-label, randomised phase 3 trial. Lancet Oncol. 2012; 13:239-46.

2. Shaw AT, Kim DW, Nakagawa $K$, Seto T, Crinó L, Ahn MJ, De Pas T, Besse B, Solomon BJ, Blackhall F, $\mathrm{Wu}$ YL, Thomas M, O'Byrne KJ, et al. Crizotinib versus chemotherapy in advanced ALK-positive lung cancer. N Engl J Med. 2013; 368:2385-94.

3. Douillard JY, Shepherd FA, Hirsh V, Mok T, Socinski MA, Gervais R, Liao ML, Bischoff H, Reck M, Sellers MV, Watkins CL, Speake G, Armour AA, et al. Molecular predictors of outcome with gefitinib and docetaxel in previously treated non-small-cell lung cancer: data from the randomized phase III INTEREST trial. J Clin Oncol. 2010; 28:744-52.

4. Planchard D, Groen HJ, Kim TM, Rigas JR, Souquet PJ, Baik CS, Barlesi F, Mazières J, Quoix EA, Curtis CM, Mookerjee B, Bartlett-Pandite AN, Tuckeret C, et al. Interim results of a phase II study of the BRAF inhibitor (BRAFi) dabrafenib (D) in combination with the MEK inhibitor trametinib (T) in patients (pts) with BRAF V600E mutated (mut) metastatic non-small cell lung cancer (NSCLC). | J Clin Oncol 2015; 33 suppl; abstr 8006.

5. Besse B, Soria J, Yao B, Kris M, Chao B, Cortot A, Mazières J, Socinski MA, Horn L, Waqar S, Barlesi F, Gray J, Moro-Sibilot D, et al. Neratinib (N) with or without temsirolimus (TEM) in patients (pts) with non-small cell lung cancer (NSCLC) carrying HER2 somatic mutations: An international randomized phase II study. Annals of Oncology. 2014; 25:v1-v41.

6. Johnson ML, Sima CS, Chaft J, Paik PK, Pao W, Kris MG, Ladanyi M, Riely GJ. Association of KRAS and EGFR mutations with survival in patients with advanced lung adenocarcinomas. Cancer. 2013; 119:356-62. 
7. Litvak AM, Paik PK, Woo KM, Sima CS, Hellmann MD, Arcila ME, Ladanyi M, Rudin CM, Kris MG, Riely GJ. Clinical characteristics and course of 63 patients with BRAF mutant lung cancers. J Thorac Oncol. 2014; 9:1669-74.

8. Aupérin A, Le Péchoux C, Rolland E, Curran WJ, Furuse K, Fournel P, Belderbos J, Clamon G, Ulutin HC, Paulus R, Yamanaka T, Bozonnat MC, Uitterhoeve A, et al. Meta-analysis of concomitant versus sequential radiochemotherapy in locally advanced non-small-cell lung cancer. J Clin Oncol. 2010; 28:2181-90.

9. De Ruysscher D, Belderbos J, Reymen B, Van Elmpt W, van Baardwijk A, Wanders R, Hoebers F, Vooijs M, Ollers M, Lambin P. State of the art radiation therapy for lung cancer 2012: a glimpse of the future. Clin. Lung Cancer. 2013; 14:89-95.

10. De Ruysscher D, Botterweck A, Dirx M, PijlsJohannesma M, Wanders R, Hochstenbag M, Dingemans a-MC, Bootsma G, Geraedts W, Simons J, Pitz C, Lambin P. Eligibility for concurrent chemotherapy and radiotherapy of locally advanced lung cancer patients: a prospective, population-based study. Ann. Oncol. 2009; 20:98-102.

11. Mauguen A, Pignon JP, Burdett S, Domerg C, Fisher D, Paulus R, Mandrekar SJ, Belani CP, Shepherd FA, Eisen T, Pang H, Collette L, Sause WT, et al. Surrogate endpoints for overall survival in chemotherapy and radiotherapy trials in operable and locally advanced lung cancer: a re-analysis of meta-analyses of individual patients' data. Lancet Oncol. 2013; 14:619-26.

12. Zhang Z, Wang T, Zhang J, Cai X, Pan C, Long Y, Chen J, Zhou C, Yin X. Prognostic value of epidermal growth factor receptor mutations in resected non-small cell lung cancer: a systematic review with meta-analysis. PLoS One. 2014; 9:e106053.

13. Fang $\mathrm{S}$, Wang $\mathrm{Z}$. EGFR mutations as a prognostic and predictive marker in non-small-cell lung cancer. Drug Des. Devel. Ther. 2014; 8:1595-611.

14. Soria JC, Brambilla E, Le Teuff G, Tsao MS, Janne PA, Hainaut P, Taron M, Kratzke R, Shepherd FA, Pignon JP. A pooled analysis to evaluate the prognosis and predictive value of EGFR mutation on survival in patients with KRAS wildtype lung adenocarcinoma. J Thorax Oncol. 2011; 6:S617.

15. Eberhard DA, Johnson BE, Amler LC, Goddard AD, Heldens SL, Herbst RS, Ince WL, Jänne PA, Januario T, Johnson DH, Klein P, Miller VA, Ostland MA et al. Mutations in the Epidermal Growth Factor Receptor and in KRAS Are Predictive and Prognostic Indicators in Patients With Non Small-Cell Lung Cancer Treated With Chemotherapy Alone and in Combination With Erlotinib. J Clin Oncol. 2005; 23:5900-9.

16. Tsao MS, Sakurada A, Cutz JC Zhu CQ, Kamel-Reid S, Squire J, Lorimer I, Zhang T, Liu N, Daneshmand M, Marrano P, da Cunha Santos G, Lagarde A et al. Erlotinib in Lung Cancer - Molecular and Clinical Predictors of Outcome. New Engl J. 2005; 353:133-44.
17. Neal JW. The SATURN trial: the value of maintenance erlotinib in patients with non-small-cell lung cancer. Future Oncol. 2010; 6:1827-32.

18. Yang P, Kulig K, Boland JM, Erickson-Johnson MR, Oliveira AM, Wampfler J, Jatoi A, Deschamps C, Marks R, Fortner C, Stoddard S, Nichols F, Molina J, et al. Worse disease-free survival in never-smokers with ALK+ lung adenocarcinoma. J Thorac Oncol. 2012; 7:90-7.

19. Blackhall FH, Peters S, Bubendorf L, Dafni U, Kerr KM, Hager H, Soltermann A, O’Byrne KJ, Dooms C, Sejda A, Hernández-Losa J, Marchetti A, Savic S, et al. Prevalence and Clinical Outcomes for Patients With ALK-Positive Resected Stage I to III Adenocarcinoma: Results From the European Thoracic Oncology Platform Lungscape Project. J Clin Oncol. 2014; 32:2780-7.

20. Zhou JX, Yang H, Deng Q, Gu X, He P, Lin Y, Zhao M, Jiang J, Chen H, Lin Y, Yin W, Mo L, He J. Oncogenic driver mutations in patients with non-small-cell lung cancer at various clinical stages. Ann Oncol. 2013; 24:1319-25

21. Mascaux C, Iannino N, Martin B, Paesmans M, Berghmans T, Dusart M, Haller A, Lothaire P, Meert AP, Noel S, Lafitte JJ, Sculier JP. The role of RAS oncogene in survival of patients with lung cancer: a systematic review of the literature with meta-analysis. Br J Cancer 2005; 92:131-9.

22. Meng D, Yuan M, Li X, Chen L, Yang J, Zhao X, Ma W, Xin J. Prognostic value of K-RAS mutations in patients with non-small cell lung cancer: a systematic review with meta-analysis. Lung Cancer. 2013; 81:1-10.

23. Shepherd FA, Altorki NK, Eberhardt WEE, O'Brien MER, Wang J, Horan JD, Foley MA, Iwata KK, Gill SC, Richardson FC, Kelly K. Prognostic and predictive roles of EGFR copy number and KRAS mutation status from the RADIANT trial of adjuvant erlotinib versus placebo. Ann. Oncol. 2014; 25: iv409-16.

24. Shepherd FA, Domerg C, Hainaut P Jänne PA, Pignon JP, Graziano S, Douillard JY, Brambilla E, Le Chevalier T, Seymour L, Bourredjem A, Le Teuff G, Pirker R, et al. Pooled Analysis of the Prognostic and Predictive Effects of KRAS Mutation Status and KRAS Mutation Subtype in Early-Stage Resected Non - Small-Cell Lung Cancer in Four Trials of Adjuvant Chemotherapy. J Clin Oncol. 2013; 31:2173-81.

25. Pécuchet N, Laurent-Puig P, Mansuet-Lupo A, Alifano M, Pallier K, Didelot A, Gibault L, Just P, Riquet M, Pimpecbarthes F Le. Different prognostic impact of STK11 mutations in non- squamous non-small-cell lung cancer. Oncotarget. 2015 Nov 25. doi: 10.18632/oncotarget.6379. [Epub ahead of print].

26. Barlesi F, Mazieres J, Merlio JP, Debieuvre D, Mosser J, Lena H, Ouafik L, Besse B, Rouquette I, Westeel V, Escande F, Monnet I, Lemoine A et al. Routine molecular profiling of patients with advanced non-small-cell lung cancer : results of a 1-year nationwide programme of the French Cooperative Thoracic Intergroup ( IFCT ). Lancet 2016; 387:1415-26. 
27. Barlesi F, Tomasini P, Fina F, Secq V, Greillier L, NanniMetellus I, Garcia S, Ouafik L. [Regional molecular genetics centers in thoracic oncology: what and who should be tested?]. Bull. Cancer. 2013; 100:737-41.

28. Lee CK, Brown C, Gralla RJ, Hirsh V, Thongprasert S, Tsai CM, Tan EH, Ho JC, Chu da T, Zaatar A, Osorio Sanchez JA, Vu VV, Au JS et al. Impact of EGFR inhibitor in non-small cell lung cancer on progression-free and overall survival: a meta-analysis. J Natl Cancer Inst. 2013; 105:595-605.

29. Cadranel J, Mauguen A, Faller M, Zalcman G, Buisine MP, Westeel V, Longchampt E, Wislez M, Coudert B, Daniel C, Chetaille B, Michiels S, Blons H, et al. Impact of Systematic EGFR and KRAS Mutation Evaluation on Progression-Free Survival and Overall Survival in Patients with Advanced Non-Small-Cell Lung Cancer Treated by Erlotinib in a French Prospective Cohort J Thorac Oncol. 2012; 7:1490-502.

30. Reck M, Popat S, Reinmuth N, De Ruysscher D, Kerr KM, Peters S, ESMO Guidelines Working Group. Metastatic non-small-cell lung cancer (NSCLC): ESMO Clinical Practice Guidelines for diagnosis, treatment and follow-up. Ann. Oncol. 2014; 25:iii27-39.

31. Wang M, Kern AM, Hulskotter M, Greninger P, Singh A, Pan Y, Chowdhury D, Krause M, Baumann M, Benes CH, Efstathiou JA, Settleman J, Willers H. EGFR-mediated chromatin condensation protects KRAS-mutant cancer cells against ionizing radiation. Cancer Res. 2014; 74:2825-34.

32. Liang K, Ang KK, Milas L, Hunter N, Fan Z. The epidermal growth factor receptor mediates radioresistance. Int. J. Radiat. Oncol. Biol. Phys. 2003; 57:246-54.

33. Renaud S, Schaeffer M, Voegeli AC, Guérin E, Meyer N, Mennecier B, Quoix E, Falcoz P, Guénot D, Massard G, Noël G. Impact of EGFR mutations and KRAS amino acid substitution on the response to radiotherapy for brain metastasis of non-small-cell lung cancer. Future Oncol. 2016; 12:59-70.

34. Johung KL, Yao X, Li F, Yu JB, Gettinger SN, Goldberg S, Decker RH, Hess JA, Chiang VL, Contessa JN. A clinical model for identifying radiosensitive tumor genotypes in non-small cell lung cancer. Clin Cancer Res. 2013; 19:5523-32.

35. Johung KL, Yah N, Desai NB, Williams TM, Lautenschlaeger T, Arvold ND, Ning MS, Attia A, Lovly CM, Goldberg S, Beal K, Yu JB, Kavanagh BD, et al. Extended Survival and Prognostic Factors for Patients With ALK-Rearranged Non-Small-Cell Lung Cancer and Brain Metastasis. J Clin Oncol. 2015; 34:123-9.

36. Gan GN, Weickhardt AJ, Scheier B, Doebele RC, Gaspar LE, Kavanagh BD, Camidge DR. Stereotactic radiation therapy can safely and durably control sites of extra-central nervous system oligoprogressive disease in anaplastic lymphoma kinase-positive lung cancer patients receiving crizotinib. Int. J Radiat Oncol Biol Phys. 2014; 88:892-8.
37. Bradley JD, Paulus R, Komaki R, Masters GA, Forster K, Schild SE, Bogart J, Garces YI, Narayan S, Kavadi V, Nedzi LA, Michalski JM, Johnson D, et al. Standard-dose versus high-dose conformal radiotherapy with concurrent and consolidation carboplatin plus paclitaxel with or without cetuximab for patients with stage IIIA or IIIB non-smallcell lung cancer (RTOG 0617): a randomised, two-by-two factorial phase 3 study. Lancet Oncol. 2015; 16:187-99.

38. Senan S, Brade A, Wang LH, Vansteenkiste J, Dakhil S, Biesma B, Martinez Aguillo M, Aerts J, Govindan R, Rubio-Viqueira B, Lewanski C, Gandara D, Choy H et al. PROCLAIM: Randomized Phase III Trial of PemetrexedCisplatin or Etoposide-Cisplatin Plus Thoracic Radiation Therapy Followed by Consolidation Chemotherapy in Locally Advanced Nonsquamous Non-Small-Cell Lung Cancer. J Clin Oncol. 2016; 34:953-62

39. Eberhardt WE, Pottgen C, Gauler TC, Friedel G, Veit S, Heinrich V, Welter S, Budach W, Spengler W, Kimmich M, Fischer B, Schmidberger H, De Ruysscher D, et al. Phase III Study of Surgery Versus Definitive Concurrent Chemoradiotherapy Boost in Patients With Resectable Stage IIIA(N2) and Selected IIIB Non-Small-Cell Lung Cancer After Induction Chemotherapy and Concurrent Chemoradiotherapy (ESPATUE). J Clin Oncol. 2015; 33:4194-201.

40. Chi A, Nguyen NP, Welsh JS, Tse W, Monga M, Oduntan O, Almubarak M, Rogers J, Remick SC, Gius D. Strategies of dose escalation in the treatment of locally advanced nonsmall cell lung cancer: image guidance and beyond. Front. Oncol. 2014; 4:156.

41. Levy A, Chargari C, Cheminant M, Simon N, Bourgier C, Deutsch E. Radiation therapy and immunotherapy: implications for a combined cancer treatment. Crit. Rev. Oncol. Hematol. 2013; 85:278-87.

42. Deutsch E, Le Péchoux C, Faivre L, Rivera S, Tao Y, Pignon JP, Angokai M, Bahleda R, Deandreis D, Angevin E, Hennequin C, Besse B, Levy A et al. Phase I trial of everolimus in combination with thoracic radiotherapy in non-small-cell lung cancer. Ann. Oncol. 2015; 26:1223-9.

43. Eberhardt ED, De Ruysscher D, Weder W Le Péchoux C, De Leyn P, Hoffmann H, Westeel V, Stahel R, Felip E, Peters S, Panel Members. 2nd ESMO Consensus Conference in Lung Cancer : locally advanced stage III non-small-cell lung cancer. Ann Oncol. 2015; 26:1573-88.

44. Travis WD, Brambilla E, Burke AP, Marx A, Nicholson AG. World health organisation classification of tumours of the lung, pleura, thymus and heart. J Thorac Oncol. 2015; 10:1240-2.

45. De Martino MC, Al Ghuzlan A, Aubert S, Assié G, Scoazec JY, Leboulleux S, Do Cao C, Libè R, Nozières C, Lombès M, Pattou F, Borson-Chazot F, Hescot $\mathrm{S}$ et al. Molecular screening for a personalized treatment approach in advanced adrenocortical cancer. J. Clin. Endocrinol. Metab. 2013; 98:4080-8. 
46. Vanni I, Coco S, Truini A, Rusmini M, Giovanna M, Bello D, Alama A, Banelli B, Mora M, Rijavec E, Barletta G, Genova C, Biello F, et al. Next-Generation Sequencing Workflow for NSCLC Critical Samples Using a Targeted Sequencing Approach by Ion Torrent PGM TM Platform. Int J Mol Sci. 2015; 16:28765-28782.
47. Schemper M, Smith TL. A note on quantifying follow-up in studies of failure time. Control Clin Trials. 1996; 17:343-6. 